FILOZOFIA

Roč. 75,2020 , č. 6

DOI: https://doi.org/10.31577/filozofia.2020.75.6.2

\title{
HEGELOVA KONCEPCIA BYROKRACIE AKO VŠEOBECNÉHO STAVU
}

\author{
MICHAL LIPTÁK, Filozofický ústav Slovenskej akadémie vied, Bratislava, SR \\ LIPTÁK, M.: Hegel's Conception of Bureaucracy as Universal Class \\ FILOZOFIA, 75, 2020, No 6, pp. $446-459$
}

This article analyzes Hegel's conception of bureaucracy in Philosophy of Right, especially in relation to its characteristic as universal class. As universal class. It is argued that's function of bureaucracy as universal class transcends its particular practical function and it has emancipatory function as well. This view is then briefly criticized via the criticism raised by young Marx. Finally, it is argued that philosophical validity Hegel's conception is intentionally and inherently linked to, in principle, contingent historical development. This is then related to current bureaucratic apparatus of European Union.

Keywords: Georg Wilhelm Friedrich Hegel - Philosophy of right - Karl Marx Bureaucracy - Universal class - European Union

\section{Úvod}

Do akej miery je Hegelova Filozofia práva zastaraným dobovým dokumentom a do akej ustavične relevantným a plodným filozofickým spisom, to je dnes predmetom debát. Ako optimistický príklad druhej pozície môžeme uviest' Axela Honnetha, podl'a ktorého možno Hegelov projekt v danom diele oživit' a ,nadviazat' opätovne na Hegelovu snahu vytvorit’ teóriu spravodlivosti na základe štrukturálnych podmienok, ktoré reálne v spoločnosti existujú “ (Honneth 2014, 3). Tento článok je len čiastkovou praktickou demonštráciou aktuálnosti Hegelovej politickej filozofie. Konkrétne sa budem venovat' Hegelovmu chápaniu byrokracie ako „všeobecného stavu“, respektíve „univerzálnej triedy“. ${ }^{1}$

\footnotetext{
${ }^{1}$ Hegelovo allgemeiner Stand sa do angličtiny štandardne prekladá ako universal class, čo zároveň korešponduje s marxistickým pojmom allgemeine Klasse. Je otázne, do akej miery je tento preklad konvenciou a do akej reflektuje reálne presvedčenie, že nemecké výrazy Stand a Klasse možno v prípade Hegela používat' v podstate synonymne. Každopádne, Peperzak (2001, 449 - 450) ukazuje, že existujú aj reálne dôvody používat' tieto výrazy ako synonymá a že vo Filozofii práva „Hegel sám používa výraz Klasse ako ekvivalentný Stand“. Nasledujúc Peperzaka používam v tomto texte oba pojmy vo vzt'ahu k Hegelovej filozofii zamenitel'ne.
} 
Téma byrokracie je v európskom kontexte bezpochyby aktuálna. Na prvý pohl'ad sa zdá, že Hegelova teória byrokracie ako stavu sledujúceho všeobecný záujem by mohla byt' vhodnou apológiou bujnejúcej európskej byrokracie. No podobne sa na prvý pohl'ad zdá, že napríklad dobová kritika mladého Marxa by bez vel'kých zmien mohla dodávat' muníciu aj súdobým kritikom Európskej únie (d’alej EÚ). Marx (1956b, 273), kritizujúc Hegela, akoby expresívne zachytával problém demokratického deficitu, ked' píše, že „byrokracia má štát, spirituálnu podstatu spoločnosti, vo svojej držbe; je to jej súkromné vlastníctvo “. A akoby kritizoval odt'ažitost' európskej byrokracie, ked' hned' nato píše, že „,v̌̌eobecným duchom byrokracie je tajomstvo, mystérium, ktoré v sebe chráni prostredníctvom hierarchie a navonok uzatvorenej korporatívnosti“. Skôr ako sa detailnejšie pozrieme na túto Marxovu kritiku, zrekonštruujeme Hegelovu apológiu, ktorá sa špecificky odvíja od chápania byrokracie ako „Všeobecného stavu“, pričom pre nás je zaujímavá práve táto Hegelova charakteristika. V následnom texte sa najprv venujem vzt'ahu deskripcie a normativity vo Filozofii práva, a vzápätí detailnejšie Hegelovmu pojmu všeobecného stavu a byrokracie ako jeho konkrétnej realizácie vo fakticky existujúcom štátnom zriadení. Marxova kritika je zároveň prezentovaná z inej strany aj ako domýšl’anie Hegelovej koncepcie, ktorá ju však v konečnom dôsledku neruší. V poslednej časti tieto koncepty vzt’ahujem na súčasný byrokratický aparát EÚ.

\section{Postup Filozofie práva}

Aby sme pochopili Hegelovo myslenie o byrokracii, treba najprv v krátkosti ozrejmit' postup a metódu Filozofie práva. Nejde o skúmanie, ktoré možno jednoducho zadefinovat' ako deskriptívne alebo normatívne. Je pravda, že Hegel svoje skúmanie na začiatku ostentatívne ohlasuje ako deskriptívne, ked' píše, že „toto pojednanie, pokial' obsahuje vedu o štáte, nemá byt' ničím iným ako pokusom pochopit’ a ukázat'štát ako niečo v sebe rozumné. Ako filozofický spis musí byt' čo najviac vzdialené od úmyslu chciet' rekonštruovat' štát, aký má byt“ (Hegel 1992,31). Treba však zároveň povedat', že Hegel sa tohto úplne nedrží a Filozofia práva obsahuje tvrdenia, ktoré sú v jednoduchom význame slova normatívne. Navrhuje napríklad inštitúcie, ktoré v danej dobe neboli univerzálne zavedené. ${ }^{2}$

Ak by sme aj predbežne akceptovali Hegelovo tvrdenie, že jeho skúmanie je deskriptívne, otázka je, v akom zmysle je deskriptívne. Ako poznamenáva Pippin (1997,

\footnotetext{
${ }^{2}$ Takou inštitúciou je napríklad parlament, ktorý v tom čase v Prusku neexistoval (Peperzak 2001, 560). Peperzak je aj preto presvedčený, že odmietnutie normatívneho skúmania v Predslove je nekonzistentné a chybné, pričom vyslovuje hypotézu, že toto Hegelovo tvrdenie mohlo byt' skôr oportunistické, aby sa vyhol cenzúre (Peperzak 1987, 104); Pinkard $(2000,457)$ je, naopak, presvedčený, že cenzúra v prípade písania Filozofie práva nehrala nijakú významnú úlohu.
} 
422), Hegel v praxi „nikdy nezdôvodňuje racionalitu moderných inštitúcií tým, že by ich jednoducho opísal a potom tvrdil, že nech sú akékol'vek, musia byt' racionálne, pretože a priori vieme, že dejiny sú racionálne“. Podl'a Hegela má íst' ostentatívne o dedukciu štátu z idey, respektíve z pojmu práva (Hegel 1992, 35), pričom východiskom je „vôl'a, ktorá je slobodná“ (Hegel 1992, 43). Má íst' teda o logické, filozofické rozvíjanie pojmov práva a slobody, ktoré samo zo seba generuje normy a inštitúcie. K napojeniu tohto logického rozvíjania na fakticky existujúce inštitúcie bude dochádzat' v situácii, ked' tieto zároveň bude možné chápat' ako uskutočnenie filozofických pojmov práva a slobody. ${ }^{3}$

No ani toto v skutočnosti nevystihuje Hegelov myšlienkový postup vo Filozofii práva. Takýto prístup by napokon musel zahŕňat' moment pomeriavania existujúcich inštitúcií voči teoretickému ideálu, pričom takýto prístup Hegel odmieta. Naopak, ,filozofia, pretože je skúmaním toho, čo je rozumné, je práve preto uchopením toho, čo je prítomné a skutočné" (Hegel 1992, 29). Historický vývoj sa tak musí prelínat's logickým vývojom pojmov. Vývoj fakticky existujúcich inštitúcií sa teda do určitej miery prelína s logickou dedukciou, hoci nie sú identické. Prelínajú sa v tom zmysle, že existencia určitých inštitúcií a štátu v istom štádiu vývoja je nevyhnutná na naštartovanie skúmania, ktoré sa prezentuje vo Filozofii práva, takže vývoj týchto inštitúcií bude do určitej miery korešpondovat's vývojom filozoficko-právneho myslenia. Neprelínajú sa v tom zmysle, že myslenie, ktoré prejasňuje racionálny význam týchto inštitúcií, nie je, respektíve - ako uvidíme neskôr - nie je úplne závislé od ich vlastného sebavnímania a umožňuje v tomto smere aj korekcie.

Filozofiu práva tak možno vnímat' ako snahu podat' také vyjasnenie vývoja inštitúcií a štátu, prostredníctvom ktorého sa zdôvodní možnost' filozofie práva a platnost' myslenia o štáte a práve, pričom vývoj inštitúcií a štátu bude možné prezentovat' aj ako vývoj pojmovej štruktúry pojmu práva, pričom ich faktická existencia dodáva matériu aj pre ich filozofickú kritiku. Márkus $(1997,17)$ týmto smerom identifikuje paralely medzi Fenomenológiou ducha a Filozofiou práva explicitne, ked' uzatvára, že „Fenomenológia inkorporuje pohl'ad čitatela - konkrétneho, dejinno-kultúrne situovaného čitatel'a; potenciálneho adresáta nastupujúcej modernity (,My“ Fenomenológie) do samotného obsahu filozofie. (...) Rovnaký formujúci princíp funguje aj vo Filozofii práva, no nie vo vzt’ahu k dejinnej, ale vo vzt’ahu k sociálnej konštitúcii subjektu modernity“.

\footnotetext{
${ }^{3}$ Podl'a Pinkarda $(2000,457)$,obsah a argumenty vo Filozofii práva predstavovali do vel'kej miery rozsiahle ospravedlnenie pruského reformného hnutia“, pričom bola písaná „,na pozadí neustálych a vel'mi ostrých diskusií ohl'adom toho, akú podobu by malo mat' Nemecko v nadväznosti na Napoleonov spektakulárny pád a vzhl’adom na konflikty medzi reformistami a reakcionármi“ (Pinkard 2000, 469).
} 
Filozofia práva je ambicióznejšou prácou ako Fenomenológia, ked’že tá ponecháva uskutočnenie absolútneho vedenia, teda stanoviska dosiahnutého v jej závere, na separátnu prácu, menovite Logiku ako vedu. Filozofia práva však má, podobne ako Logika, na konci zdôvodnit' sám pojem - v tomto prípade pojem práva -, ktorý je zároveň východiskom, takže má dôjst' k uskutočneniu tohto pojmu; no na rozdiel od logiky sa toto uskutočnenie deje cez oblast' dejinnej náhodnosti, podobne ako to bolo vo Fenomenológii. Vo Filozofii práva sa tak logika intímne spája s kontingentnou sociálnou a politickou realitou.

\section{Stavy}

Hegel skúma byrokraciu v rámci vládnej moci najmä v $§ \S 287$ až 297 Filozofie práva. Prvýkrát sa však zjavuje pri téme „,v̌eobecného stavu“ a práve pri pojme „stavu“ sa treba pristavit'. Spoločnost' podl'a Hegela, pochopitel'ne, nie je len náhodným agregátom jednotlivcov, ale štruktúrovanou masou, pričom stavy predstavujú základné štrukturálne stavebné bloky. Hegel ich najprv identifikuje na majetkovom, „materiálnom“ princípe: masy sa delia „vo zvláštne systémy potrieb, ich prostriedkov a prác, spôsobov uspokojovania a teoretického a praktického vzdelávania - v systémy, ktorým sú jednotlivci pridelení -, v rozdiel stavov" (Hegel 1992, 233).

Ak však aj rozdiel stavov - alebo, ak chceme, tried - je fakticky daný rozdielnymi materiálnymi potrebami a spôsobmi ich uspokojovania, pojmové rozlíšenie stavov prebieha na iných líniách. Hegel $(1992,233)$ určuje stavy „,̌o do роjmu ako 1. substanciálny alebo bezprostredný stav, 2. reflektujúci alebo formálny stav a konečne ako 3. všeobecný stav“. Toto pojmové rozlíšenie je hrubou aplikáciou základného rozdelenia Logiky na spoločenskú oblast'. V Logike Hegel jednoznačne spája dve časti objektívnej logiky - bytie a podstatu - s reflexiou a bezprostrednost'ou, ked' napíše, že „treba pokladat' pojem za čosi tretie, pristupujúce k bytiu a podstate, k bezprostrednu a reflexii. Bytie a podstata sú takto momentmi jeho stávania, kým on je ich protikladom a pravdou, a to ako identita, v ktorej zanikli a sú obsiahnuté" (Hegel 1986, 215). Pojem - ktorý je zavŕšením subjektívnej logiky - je, ako vieme, univerzálny.

Fakticky tieto tri stavy korešpondujú na jednej strane s pol'nohospodármi ${ }^{4}$ a inými vlastníkmi pôdy, ktorí sú zviazaní s pôdou a prírodnými cyklami, na druhej strane so stavmi remesla, priemyslu a obchodu, pričom okrem iného zahíňal tak majitel'ov tovární, ako aj robotníkov, ktorí v nich pracovali, a na tretej strane so štátnou správou, so štátnymi úradníkmi, respektíve štátnymi zamestnancami vrátane učitelov, vojakov a podobne. Pokial' ide o zdroj obživy, členovia všeobecného stavu môžu

\footnotetext{
${ }^{4}$ Pričom konkrétne mal Hegel na mysli najmä dedičných vlastníkov väčšieho množstva pôdy v Prusku, tzv. junkerov (Peperzak 2001, 450).
} 
využívat' „bud” súkromný majetok, alebo sú odškodňovaní štátom“ (Hegel 1992, 236). Všeobecný stav môže byt' v tejto etape iba avizovaný ako štátna správa, ked’že Hegelovo skúmanie Sittlichkeit tu ešte nedospelo na úroveň štátu.

Hegel sa tu teda jednoznačne usiluje inkorporovat' všeobecnost' pojmu z Logiky do reálne existujúcej spoločenskej sféry. Prepojenie fakticity a logických dištinkcií je však už v tomto momente problematické. V čom presne? Hegel sa v tejto etape jednoznačne ešte snaží predstavit' istú prírodnú, materiálnu základňu pre štát a vyvodzovat' dištinkcie takpovediac $\mathrm{z}$ tejto materiality - teda $\mathrm{z}$ materiálnych potrieb a ich uspokojovania. Rodina je tak „prvou základňou“ štátu a stavy sú „druhou základňou“ (Hegel 1992, 233). Problém tkvie v tom, ako tieto základne prepojit’ s logickou štruktúrou. Winfield $(1991,247) v$ tomto smere kritizuje Hegela za to, že ak je rozdiel stavov vyvodený z uspokojovania potrieb, tak ich trojdelenie prevzaté z Logiky je nekonzistentné a je to v tomto bode cudzí výkladový prvok. Všeobecný stav má len „,pracovnú, záujmovú identitu odvodenú zo sféry verejnej správy, a nie vyvodenú zo spôsobov získavania obživy, ukotvených v samotných trhových vzt’ahoch“. Pojem všeobecného stavu sa tak konceptuálne rozpadá, ked’že ho možno vnímat' bud' ako špecifický stav z ekonomického hladiska, no vtedy nie je všeobecným, alebo ako všeobecný, no potom o ňom $\mathrm{v}$ reálnej sociálnej sfére vôbec nemá zmysel hovorit' ako o špecifickom stave.

Problémy sa tým nekončia. Na opačnom póle, v prípade ,substanciálneho stavu“, je z iného dôvodu problémom spojenie tohto logického pojmu s rol’níckym stavom. Problémom je totiž fakt, že ako nejaká separátna, špecifická trieda bol tento stav fakticky už v Hegelovej dobe v procese zániku, a nejavil sa teda nijako logicky nevyhnutný. Marx preukázal prostredníctvom koncepcie „diferenciálnej renty“ to, že pol'nohospodárstvo je rovnakou súčast'ou kapitalistickej výroby ako továreň či manufaktúra (Marx 1956a, 161). ${ }^{5} \mathrm{Ak}$ však dochádza $\mathrm{k}$ faktickému zániku jedného $\mathrm{z}$ týchto korešpondujúcich stavov, potom musíme povedat' bud' to, že sa tým rozpadá aj Hegelovo logické členenie, alebo musíme prerušit' intímne spojenie logiky s fakticitou a tvrdit', že čisto teoretická koncepcia si zachováva platnost' nezávisle od toho, či $\mathrm{s}$ ňou niečo fakticky korešponduje $\mathrm{v}$ realite; tým sa však zásadným spôsobom narúša Hegelov celkový dialektický argument, v ktorom sú spoločenské delenia na stavy vyvodzované paralelne s deleniami z Logiky.

Riešením by mohlo byt' práve chápanie „záujmovej identity“, ktorú Winfield vyššie chápe ako cudzí element $\mathrm{v}$ diferenciácii stavov, ako - naopak - kl'úč $\mathrm{k}$ rozdeleniu stavov. Vzt'ah k prírode ako záujem o bezprostredno, vzt’ah k vlastným individuálnym potrebám ako reflexia a úsilie integrovat' všetky záujmy ako záujem

\footnotetext{
${ }^{5}$ Marx v koncepcii diferenciálnej renty vychádzal z Ricarda; porov. Marx (1956a, 196).
} 
o všeobecno by tak boli definičnými momentmi. Logická štruktúra by sa tak uskutočnila v realite prostredníctvom dvoch kontingentných skutočností: 1. prostredníctvom dejinne náhodnej rôznosti spôsobu uspokojovania materiálnych potrieb v rôznych spoločenských, respektíve ekonomických sférach, pričom tento moment je rozhodujúci z hl’adiska genézy; 2 . prostredníctvom náhodného rozdielu v záujmoch jednotlivcov, pričom tento moment je rozhodujúci z hladiska reprodukcie daného členenia. $\mathrm{V}$ takom prípade by ani zjednotenie spôsobu uspokojovania materiálnych potrieb, ku ktorému dochádza v modernej kapitalistickej spoločnosti, nemalo vplyv na platnost' logickej štruktúry, a zároveň by neprerušovalo ani spojenie s fakticitou. Hegel (1992, 236), zdá sa, takisto považuje toto druhé zakotvenie za klúčové, ked’ píše, že „na to, ku ktorému zvláštnemu stavu náleží indivíduum, majú svoj vplyv naturel, pôvod a okolnosti, ale posledné a bytostné určenie tkvie v subjektívnom mieneni a zvláštnej lubovôli, ktorá si v tejto sfére dáva svoje právo, svoje zásluhy a svoju čest', takže to, čo sa v nej deje s vnútornou nutnostou, je zároveň sprostredkované l'ubovôl'ou a má pre subjektívne vedomie podobu diela jeho vôle“.

Zavedenie subjektívnych záujmov ako definičného momentu neutralizuje vyššie uvedenú kritiku, hoci stále platí, že v procese Hegelovho výkladu nie je tento príklon $\mathrm{k}$ subjektívnym záujmom dostatočne zdôvodnený. Korešponduje však s faktickou situáciou. Vzhl'adom na to, že Hegel odmieta riešit' otázku l’udskej prirodzenosti a fixovat' rozdielne záujmy v objektívnych rozdieloch l'udskej duše, je jeho logické členenie závislé od faktickej existencie rôznych druhov l’ubovol’ných záujmov medzi masami, pričom nie je t’ažké predstavit' si, že by aj zo štrukturálnych dôvodov dochádzalo k zjednocovaniu l’udských záujmov. Keby Hegel ešte dôslednejšie vnímal štrukturálne zmeny prichádzajúce s rozmachom kapitalizmu a chápal by substanciálny stav ako fakticky zanikajúci, zrejme by sa tomuto problému venoval podrobnejšie; no ked’že ho tak nevnímal, nemal dôvod svoje dištinkcie spochybňovat'. Ak dnes máme dôvod vnímat' tieto rozdielne záujmy, má pre nás v súčasnosti stále význam zaoberat' sa Hegelovou dištinkciou.

\section{Byrokracia}

Pre modernú spoločnost' je rozhodujúcou prítomnost' určitého všeobecného stavu. Ten sa následne $\mathrm{v}$ konečnom dôsledku konkretizuje $\mathrm{v}$ štátnej byrokracii. Zamestnaním byrokracie ako všeobecného stavu sú všeobecné záujmy (Hegel 1992, 236). Moralita, schopnosti, vzdelanie, zručnosti a charakter majú určujúcu funkciu pri pôsobení v štátnej byrokracii (Hegel 1992, 237, 311). ${ }^{6}$ U Hegela tak môžeme hovorit' o meritokracii (porov. Avineri 1972, 159).

${ }^{6}$ Rozhodujúcimi podmienkami, naopak, nie je „prirodzená osobnost’ či narodenie“, pretože medzi
prirodzenost’ou jednotlivca a objektivitou vládnych činností „nie je žiadne bezprostredné spojenie“ 
Štátna správa má byt' zároveň vo všetkých ohl'adoch, teda aj v materiálnom, nezávislá od súkromných záujmov (Hegel 1992, 328). Hoci Hegel zvažuje dva možné zdroje obživy pre členov všeobecného stavu - a síce nahromadené bohatstvo a štátny plat -, je jednoznačné, že preferuje druhý spôsob odmeňovania, pretože ten je v súlade s meritokratickými ideami a zabezpečuje prístup do štátnej správy aj pre schopných, no nemajetných. Zároveň ,úradnícky vzt’ah nie je zmluvným vzt’ahom“ na vykonanie určitej činnosti, ale úradnícky zamestnanec „kladie do tohto vzt’ahu hlavný záujem svojej duchovnej a zvláštnej existencie“ (Hegel 1992, 327 - 328). Podobne ako v prípade súdov (Hegel 1992, 256), ciel’om štátnej správy je subsumpcia, respektíve „prechod od všeobecného k zvláštnemu“, čo vyžaduje jednak del'bu práce podl'a zvláštnych odvetví života, a jednak ich hierarchickú vertikálnu organizáciu (Hegel 1992, 325). V konečnom dôsledku ide o ,udržiavanie všeobecného štátneho záujmu a zákonnosti v zvláštnych právach a v ich prevedení na onen záujem“ (Hegel 1992, 324). Nejde teda ani tak o schopnost' konat' absolútne bezchybne, ale skôr o schopnost' správne nastavit' priority tak, aby dochádzalo $\mathrm{k}$ reprodukcii zriadenia, ktoré $\mathrm{v}$ sebe daný byrokratický aparát zahŕňa, a aby pritom nedochádzalo $\mathrm{k}$ degradácii daného štátneho zriadenia, jeho zásad, princípov a hodnôt.

Je táto byrokracia len jedným $\mathrm{z}$ aspektov štátneho zriadenia, alebo ide o význačnú inštitúciu z hl'adiska „vtel'ovania“ všeobecna? Avineri $(1972,160)$ tvrdí, že v konečnom dôsledku ,tu máme model byrokracie, ktorý je takmer identický s weberovským ideálnym typom“. Shaw $(1992,383)$ proti tomu správne poukazuje na dôležitý rozdiel v chápaní byrokracie u Webera a Hegela, pričom ho demonštruje odkazom na aristotelovskú dištinkciu medzi zručnost'ou $(\tau \dot{\chi} \chi v \eta)$ a praktickou múdrost'ou

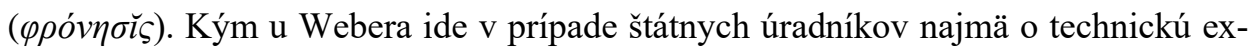
pertízu pri dosahovaní určitých vopred stanovených ciel’ov, v prípade Hegela ide o subsumpciu, ktorá zahŕňa aj úsudok a, a fortiori, chápanie zmyslu celého celku právnych noriem, teda poznanie všeobecného záujmu. Úradník tak nielenže vykonáva špecializovanú činnost', ale vo výkone svojej špecializovanej činnosti uchováva právne normy, a uchováva štátny záujem ako všeobecný záujem.

Je pravda, že čisto technokratické chápanie štátnej správy na strane Hegela by bolo neprimerane zužujúce. Všeobecný stav a všeobecný záujem má byt’ totiž fakticky integrujúcim momentom, ktorý zlad’uje partikulárne záujmy. Tieto vznikajú prirodzene a priamo v občianskej spoločnosti, kde ,je každý sám sebe účelom, a všetci ostatní sú mu ničím“ (Hegel 1992, 219). Toto je však pre Hegela stav, ktorý prirodzene smeruje aj k svojmu prekonaniu, nakol'ko „sebecký účel vo svojom

(Hegel 1992, 326). Peperzak $(2001,545)$ poznamenáva, že v Hegelovej dobe toto nebola nevyhnutne jediná podmienka, a že stála „, protiklade $\mathrm{k}$ určitým privilégiám, ktoré stále existovali v Prusku v roku $1820 “$. 
uskutočnení, takto podmienený všeobecnost’ou, zakladá systém všestrannej závislosti, takže subsistencia a blaho jednotlivca a jeho právna existencia sú späté so subsistenciou, blahom a právom všetkých, sú na tom založené a len v tejto súvislosti skutočné a zaistené" (Hegel 1992, 220). Uskutočňovanie sebeckých účelov tak implikuje všeobecný záujem, pričom Hegel analyzuje prípady - napríklad cechy, korporácie, pričom z dnešného hladiska tam možno zaradit' aj odbory - ked' dochádza k čiastočnému zlad’ovaniu týchto partikulárnych záujmov medzi určitými záujmovými skupinami. Avšak $\mathrm{k}$ úplnému zladeniu $\mathrm{v}$ rámci občianskej spoločnosti ako takej z jej podstaty nemôže dôjst'; $\mathrm{k}$ úplnej realizácii všeobecného záujmu musí dôjst' až v rámci reálne existujúceho stavu, ktorý stojí nad občianskou spoločnost'ou. ${ }^{7}$

Rozvoj byrokracie - pri zachovaní vyššie uvedených podmienok (meritokracia) - je teda zároveň emancipáciou a vylepšuje pôdu na uskutočňovanie všeobecného záujmu. Štátna byrokracia tak nie je len miestom faktického uskutočňovania všeobecného záujmu $\mathrm{v}$ jednotlivých prípadoch, ale $\mathrm{s}$ faktickým rozvojom štátnej byrokracie dochádza aj k tomu, že všeobecno ako také sa stáva záujmom más (porov. Hegel 1992, 329). Ak sa všeobecno stane masovým záujmom, otvára sa cesta k masovému pochopeniu štátu ako rozumného, ako uskutočnenia pojmu práva, teda ako konečného rozvinutia slobody.

Technicky vzaté, vyššie spomínané charakterové či vzdelanostné črty alebo zručnosti u úradníkov sú empirickou požiadavkou pri akejkol'vek byrokracii, ak má táto vôbec fungovat'; a to bez ohl'adu na zriadenie, v rámci ktorého funguje. Filozofia práva je však v prvom rade rozvíjaním pojmu slobody a pre Hegela byrokracia nemôže sledovat' skutočne všeobecný záujem, bez ohl'adu na dobrú vieru konkrétnych úradníkov, ak neoperuje v takom štátnom zriadení, kde sú jeho členovia formálne slobodní. ${ }^{8}$ Bez splnenia tejto požiadavky môže byrokracia aj pri dobrých úmysloch zaist'ovat' len partikulárne záujmy; vo vzt'ahu k značnej časti členov sú totiž hranice kasty alebo otrocký či nevol'nícky stav nepreniknutel'né bariéry, ktoré treba najprv s ciel'om emancipácie odstránit'. Ked' už sú odstránené, štátna byrokracia sa môže plne stat' nástrojom d’alšej reálnej emancipácie a rozširovania reálnej slobody. Hegel bol presvedčený, že v tomto ohl'ade byrokracia fakticky pôsobila už v jeho dobe a že formálna sloboda bola dostatočná.

\footnotetext{
${ }^{7}$ K partikulárnym záujmom v rámci občianskej spoločnosti bližšie pozri Hardimon (1994, 189 - 205). 8 Špecifickým prípadom je prípad chudoby, ked’že chudobný jedinec je reálne do značnej miery neslobodný. Vo Filozofii práva sa Hegel venuje problému chudoby (Hegel 1992, 263 - 266), pričom rozpoznáva jednak to, že kapitalistické politicko-ekonomické zriadenie zo svojej podstaty produkuje oblast' chudoby, a jednak to, že chudoba spôsobuje aj mravnú degeneráciu a znemožňuje venovat' sa veciam verejným. Podla Hardimona (1994, 236 -250) Hegel nedokázal problém chudoby uspokojivo riešit', čo si aj uvedomoval, a predstavuje to pre neho najzásadnejší problém pri realizácii ambícií Filozofie práva, teda vykázaniu štátu ako inherentne rozumného.
} 


\section{Ambície byrokracie a Marxova kritika}

V byrokracii nejde len konkretizáciu všeobecného záujmu ako subjektívneho záujmu úradníkov; z vyššie uvedeného vyplýva, že poslaním byrokracie je aj fakticky rozširovat' svoju vecnú pôsobnost'. Otázka je, do akej miery bral sám Hegel túto koncepciu byrokracie filozoficky vážne. Hegel najmä vo svojom ranom období oceňoval význam revolúcií, napríklad práve pri prelamovaní bariér otroctva, no vo svojom neskoršom období sa snažil predostriet' filozofiu štátu a dejín, ktorá by revolúcie nevyžadovala, priam by im predchádzala. ${ }^{9}$ To si vyžaduje konkrétne vyjadrenie všeobecnosti v existujúcom systéme a štátna byrokracia je $\mathrm{v}$ tom skôr inštitúciou, ktorá je prirodzene poruke. Plodnost' tohto postupu „,vtel'ovania“ fundamentálnych požiadaviek do reálne existujúcich inštitúcií otestujeme, ked’ Hegela konfrontujeme s Marxom, ktorý bral Hegelove univerzalistické ambície vážne, no zároveň osobne nepovažoval za nevyhnutné viazat' sa na existujúci politický systém.

Potom neprekvapí, že Marx $(1956 b, 271)$ v tomto smere kritizuje Hegela za to, že len ,predkladá empirický opis byrokracie, ktorý sčasti zodpovedá skutočnosti, sčasti však predstave, ktorú má o svojom bytí samotná byrokracia“, a následne konštatuje, že „Hegel dáva svojej logike politické telo; nepodáva logiku politického tela“ (Marx 1956b, 274). „Vtelenie“ logiky je u Hegela, samozrejme, očakávaným dôsledkom jeho myšlienkového postupu. $V$ tomto smere je správne, že aj sebavnímanie byrokracie do určitej miery vchádza do filozofickej deskripcie - toto sebavnímanie je totiž takisto súčast’ou dejinného vývoja štátu (porov. Pippin 1997, 167). Podl’a Marxa u Hegela v tomto procese dochádza k úplnému hypostazovaniu empírie, úradníckych ilúzií a k prekrytiu skutočnej logiky byrokracie. Avineri $(1968,51)$ Marxovu vlastnú pozíciu zhrnul tak, že aj ked' byrokracia nie je jednoduchou reflexiou socioekonomických síl, predsa je preňho „obrazom vládnuceho sociálneho poriadku, pričom tento obraz je skreslený nárokom na všeobecno“.

Marxova reformulácia Hegelovho univerzalizmu vyžaduje, aby sa z filozofického hladiska všeobecno odpútalo od reálne existujúcej byrokracie: „V pravom štáte nejde o to, aby sa každý občan mohol venovat' všeobecnému stavu ako zvláštnemu stavu, ale o to, aby všeobecný stav bol schopný byt' skutočne všeobecným stavom, teda aby mohol byt' stavom každého občana. Hegel však vychádza z predpokladu pseudo-všeobecného, iluzórne všeobecného stavu, zo zvláštnej stavovskej všeobecnosti““ (Marx 1956b, 277). V konečnom dôsledku je napokon nevyhnutné, aby sa všeobecno odpútalo od pojmu

\footnotetext{
${ }^{9}$ Buck-Morss (2009, 48 - 74) argumentuje, že slávna dialektika pána a raba vo Fenomenológii ducha je priamo inšpirovaná vtedajšou haitskou revolúciou, a predostiera revolúciu ako nevyhnutnú podmienku oslobodenia z rabstva. Zároveň však tvrdí, že Hegel postupne akúkol'vek predstavu revolúcie ako emancipačnej opúšt’al.
} 
stavu, ked’že „stav má vôbec ten význam, že základom existencie jednotlivca je rozdiel, odtrhnutie“ (Marx 1956b, 309). Všeobecný stav je v istom zmysle contradictio in adiecto. A riešením tejto kontradikcie je pre Marxa odstránit' substantívum.

Marx teda Hegelove tri stavy či triedy, vyvodené z vývoja pojmu sloboda, priečne presekáva svojou vlastnou koncepciou triedy na dvoje, kde na jednej strane sa nachádzajú triedy udržiavajúce tento stav rozdelenia či odtrhnutia, a na druhej strane trieda, ktorej ide o odstránenie tohto stavu. Toto delenie prebieha napríklad Hegelovým formálnym stavom, kde oddeluje kapitalistov, napríklad vlastníkov tovární, od proletariátu. ${ }^{10}$ Proletariát je potom pre Marxa všeobecným stavom, respektíve univerzálnou triedou, no nie preto, že by všeobecno bolo jeho záujmom, ale preto, lebo ako jediný je v pozícii, v ktorej má podl'a neho zmysel žiadat' odstránenie všetkých stavov a nastolenie skutočnej všeobecnosti. Lukács $(1971,71)$ to vyslovil najjasnejšie, ked' napísal, že ,revolučné vít’azstvo proletariátu neimplikuje, ako v prípade iných tried, bezprostrednú realizáciu sociálne danej existencie triedy, ale (...) jeho seba-anihiláciu“. Vo fakticky existujúcom proletariáte prirodzene existuje rozdelenie, respektíve protirečenie: medzi bezprostrednými záujmami proletariátu - napríklad vyššie mzdy, lepšie pracovné podmienky, dôslednejšia politická reprezentácia - a dlhodobým záujmom - zrušenie tried ako takých, a teda aj ich politických reprezentácií. Lukács však toto protirečenie označuje za „dialektické“, ked’že je to protirečenie, ktoré možno v dejinách prekonat' vd’aka revolučnej akcii. Ak u Hegela v prípade opisu byrokracie dochádza $\mathrm{k}$ prelínaniu deskriptívneho a normatívneho, o to viac to platí u Marxa. Proletariát ako všeobecný stav - teda ako stav revolučný a sebaanihilujúci je v skutočnosti normatívny pojem, nie deskriptívny.

Marx v tomto Hegelovu logiku ani tak neodmieta, skôr ju domýšl’a do dôsledkov. Lukács $(1971,147)$ správne poznamenáva, že predstava, že dejiny mali mat' koniec, ktorý navyše Hegel „odhal'oval“ vo svojej dobe, je „t'ažko pochopitel’ná vôbec z hl'adiska jeho metódy“. Striktná aplikácia Hegelovej logickej metódy by skutočne nevyhnutne vyžadovala v istom momente odstránit’ akúkol’vek partikularitu v spoločnosti. Hegel nejde do takých dôsledkov určite aj preto, lebo odstránenie partikularity nepokladá za reálnu možnost'. Zároveň však po tejto „skúške Marxom“ možno vyvodit, že všeobecný stav vôbec nemal byt' svetským korelátom absolútnej idey. Všeobecno sa v spoločnosti nemôže kompletne realizovat' na úrovni bytia; môže sa plne

\footnotetext{
${ }^{10}$ Proletariát v rámci Hegelovej koncepcie spadá do formálneho stavu, teda do občianskej spoločnosti, spolu s remeselníkmi a majitel'mi tovární. Hegel sa však téme proletariátu bližšie nevenoval. Peperzak $(2001,464)$ zavádza pojem proletariát pri výklade pasáží z Filozofie práva, ktoré sa venujú problému chudoby, respektíve luzy. To je úplne nepresvedčivé a podl’a mňa nesprávne. Hardimon $(1994,237)$ prepája pojem luzy skôr s Marxovým pojmom lumpenproletariát, čo je prinajlepšom len približne správne; prelína sa to však aspoň $\mathrm{v}$ čiastočne pohŕdavom prístupe, ktorý Hegel $\mathrm{k}$ luze a Marx k lumpenproletariátu majú.
} 
konkretizovat' len na úrovni záujmu či myslenia. Z hl'adiska Hegelovej logiky je teda, dá sa povedat', byrokracia večne len na ceste $\mathrm{k}$ absolútnemu všeobecnu, a vôbec realizovatel'ný ideál byrokracie je len na úrovni životného poslania: v pojme života (Hegel 1986, 409 - 410) totiž subjektívny účel (subjektívny záujem o všeobecné záležitosti) kladie prostriedok (byrokratický aparát), „tomuto prostriedku je však imanentný a realizuje sa v ňom ako účel identický so sebou“ "(teda chápe a realizuje sa ako životné poslanie). Život s nevyhnutnost'ou uspokojovat' základné potreby je v konečnom dôsledku stále do istej miery partikulárny a konečné prekonanie takejto partikularity vyžaduje prekonanie života, potrieb či nutnosti práce. Toto nie je v konečnom dôsledku možné a z tohto hladiska sa aj možnosti revolúcie javia ako nevyhnutne limitované. Pre Hegela je tak riešením priznanie úlohy „strážit“ všeobecno v živote spoločnosti štátnej byrokracii ako kandidátovi, ktorý sa ho dokáže chopit' minimálne na základe vlastného sebachápania a sebavnímania. ${ }^{11}$ Kontaminovanie Hegelovej deskripcie subjektívnymi momentmi je tak jednak cenou za umiernenú a realistickú politiku, jednak vyplýva $\mathrm{z}$ jeho logiky.

Hegelov výklad neodstraňuje napätia a protirečenia modernej spoločnosti, len sa ich snaží optimálnym spôsobom organizovat'. V tom má, paradoxne, Hegelov výklad výhodu. Marx neobjavil a neodstránil Hegelove „chyby“, skôr sa chopil protirečení, ktoré Hegel cielene zanechal nerozriešené, a pokúsil sa ich radikálne, absolutizujúco reinterpretovat'.

\section{Záver: staré dilemy v novej dobe}

Predchádzajúci výklad vymedzil a vyznačil filozofický priestor uvažovania o byrokracii a identifikoval oblasti napätí a protirečení. Čisto teoreticky sú tieto spory nerozhodnutel'né a fillozofický výklad musí byt' napokon nevyhnutne vtelený. Oba prístupy si z definície vyžadujú potvrdenie v dejinnej politickej praxi. Po páde totalitných režimov v Európe a rozširovaní spoločného európskeho projektu (tak rozširovaní geografickom, ako aj rozširovaní právomocí) sa istý čas zdalo, že dejiny dali za pravdu Hegelovi proti Marxovi; a to špecificky vzhl'adom na to, že proces európskej integrácie sa niesol rozsiahlym technokratickým byrokratickým aparátom a postupoval vpred napriek dlhodobo rozpoznávanému demokratickému deficitu. Očakávalo sa, že európske spoločenstvá nebudú riešit' len praktické problémy, ale každodennou, efektívnou, úspešnou správou vecí verejných budú pôsobit' emancipačne a vytvárat' skutočne uvedomelú, vnútorne zjednotenú európsku komunitu. Kreatívne neurčitá požiadavka „stále užšieho spojenectva“ [union sans cesse plus étroite] z Rímskej zmluvy od počiatku stimulovala predstavy o budúcej politickej únii (Mody 2018, 75).

${ }^{11}$ U Marxa sa, naopak, deskripcia všeobecného stavu - proletariátu - dostáva v konečnom dôsledku do rozporu s tým, ako proletariát, teda pracujúca trieda, vníma samu seba. 
Otras v ekonomickej štruktúre počas krízy v roku 2008 však vrátil vyššie opísané dilemy spät' do hry. Na jednej strane inštitúcie EÚ začali byt' kritizované presne v tej línii, že im nejde o všeobecný záujem, ale sú len skreslenou projekciou existujúcich sociálnych vzt’ahov, existujúcich ekonomických nerovností atd'. Na druhej strane sa začali ukazovat' iracionálne prvky európskej byrokracie, ako aj jej systematická nepripravenost' v niektorých záležitostiach - napríklad funkcia Európskej centrálnej banky, ktorá sa ukázala počas dlhovej a menovej krízy. Výsledkom kompromisov medzi krajinami boli konkrétne základné zásady - stabilita cien a limity na štátne dlhy. Tieto sa však postupne stali abstraktnými dogmami presadzovanými európskou byrokraciou neflexibilne a bez toho, aby sa zaoberali účelom týchto zásad, a najmä bez toho, aby boli podrobované hlbšej kritickej analýze. V presadzovaní takýchto „európskych záujmov" však zároveň európska byrokracia postupne vnímala zmysel svojej existencie. ${ }^{12}$ Bolo len otázkou času, kedy sa takto postavené európske záujmy dostanú do dostatočne ostrého kontrastu s inými partikulárnymi záujmami, najmä tými, ktoré sa často arbitrárne skrývajú pod hlavičku „národné“. Referendum o brexite je vyvrcholením tohto procesu.

Všetky tieto možnosti zlyhania anticipovala Marxova kritika Hegelovho chápania byrokracie. Je možné, že najdôležitejšia otázka je, do akej miery vôbec fungoval empirický predpoklad, na ktorom medzi Hegelom a Marxom nenájdeme spor: teda do akej miery v Hegelovom opise skutočne ide o sebavnímanie byrokracie. Otázka teda znie, či sa v nejakom bode európski úradníci aspoň subjektívne „povzniesli“ nad partikulárne problémy svojich vymedzených oblastí a vnímali svoju úlohu z hl’adiska čo i len vágne uchopeného „Všeobecného záujmu“; respektíve či to niekedy robila EÚ ako celok prostredníctvom svojich najvyšších reprezentantov. Zdá sa to skôr raritné. Je pravda, že v procese svojho značne náhodného, „námesačného“ postupu od obchodnej smerom k politickej únii došlo k formulovaniu určitého súboru „európskych hodnôt“". Tieto však nie sú chápané ako univerzálne.

Paradoxne by cestou vpred mohol byt' určitý byrokratický ,akceleracionizmus“": rozsiahlejšia integrácia na úrovni EÚ, teda väčšie rozširovanie právomocí a rozširovanie pôsobnosti zásady subsidiarity, čo by rozšírilo pôsobnost’ byrokratického aparátu ako „prostriedku“ realizácie všeobecného záujmu. Je napríklad široko akceptované, že monetárna únia je z podstaty nefunkčná bez fiškálnej únie (porov. Mody 2018, 3 - 4; Stiglitz 2016, 85 - 123). Prehlbovanie integrácie týmto smerom by bolo racionálne, a zároveň by vyžadovalo myslenie ponad partikulárne záujmy, pričom by motivovalo ku kritickému a kreatívnemu premýšlaniu úlohy a zmyslu európskej

${ }^{12}$ Ako poznamenáva Mody $(2018,287)$, ,neúplná monetárna únia bola postavená ideologicky: fiškálna úspornost' a záväzok nízkej inflácie zabezpečia potrebnú stabilitu. Z tejto ideológie, dnes už hlboko zakorenenej, sa stala úsporná identita Európy“. 
byrokracie. Na druhej strane tento subjektívny záujem o všeobecno ako taký musí byt' prítomný ako určitý jednotiaci étos, pričom toto sledovanie všeobecného záujmu musí prechádzat' všetkými, aj tými najväčšmi technokratickými oblast'ami európskej byrokracie. Len tak má európsky projekt vôbec šancu konfrontovat' sa s protichodnými silami, na ktoré pri rozširovaní pôsobností narazí, a pritom byt' zároveň projektom emancipačným. V dnešnej situácii, zdá sa, tento druhý aspekt chýba, pričom vôla $\mathrm{k}$ širšej integrácii sa oslabila. ${ }^{13}$

Hegelovu koncepciu byrokracie v európskom projekte možno stále rehabilitovat'. ${ }^{14}$ Istým spôsobom sa však na ešte vyššej, globálnej úrovni vracia do hry aj onen archaický, v Hegelovej dobe fakticky zanikajúci moment stavovského trojčlenenia vo forme „substanciálneho stavu“. Nejde už o pol'nohospodárov ani o nič podobné. No podobným substanciálnym vzt’ahom k prírode ako fundamentálnej materiálnej základni teraz už však - ako bolo avizované vyššie - v podobe ,záujmu“, sa vyznačujú environmentalistické hnutia. Vzhl'adom na konsenzus vedcov vo veci globálneho otepl'ovania a urgentnost' riešenia tohto problému je dnes už jednoznačné, že ekologický záujem je najvyšším všeobecným záujmom. Substanciálny stav sa môže znova zhmotnit', respektíve vtelit' vo všeobecnom; a zároveň tým umožnit' všeobecnému stavu byt' stavom skutočne všeobecným. Byrokracia by tak mala byt' hlavným ekologickým hnutím.

Ambíciou tohto textu bolo zasadit' tieto témy do kontextu Hegelovej politickej filozofie a naznačit' ich miesto $v$ jeho dialektickom argumente. Marxistická kritika je vždy viac či menej poruke, ked’že v konečnom dôsledku je jej jedno, čo si úradníci či už ako jednotlivci, alebo ako masa - myslia. Sústavná relevancia Hegelovej koncepcie tkvie v tom, že umožňuje pregnantne klást' otázky, ktoré sú pre úspešné fungovanie byrokracie klúčové, no zaujatí praktickou správou aj „európskych záležitostí“ ich prehliadame.

\section{Literatúra}

AVINERI, S. (1968): The Social and Political Thought of Karl Marx. Cambridge: Cambridge University Press. DOI: https://doi.org/10.1017/CBO9781139171410

AVINERI, S. (1972): Hegel's Theory of the Modern State. Cambridge: Cambridge University Press. DOI: https://doi.org/10.1017/CBO9781139171441

BUCK-MORSS, S. (2009): Hegel, Haiti and Universal History. Pittsburgh: University of Pittsburgh Press. HARDIMON, M. O. (1994): Hegel's Social Philosophy: The Project of Reconciliation. Cambridge: Cambridge University Press. DOI: https://doi.org/10.1017/CBO9780511624773

\footnotetext{
${ }^{13}$ Archetypálnou udalost’ou je nezvládnutie gréckej dlhovej krízy. Varoufakisov (2017) memoár $\mathrm{v}$ tomto smere poukazuje tak na fundamentálnu medzerovitost' a nedostatočnost' európskej byrokratickej infraštruktúry, ako aj na partikulárne až tribalistické záujmy jednotlivých európskych inštitúcií, demonštrované napríklad alibizmom prezidenta Európskej centrálnej banky Maria Draghiho. ${ }^{14}$ Shaw $(1992,387)$ pokladá Hegelovu koncepciu byrokracie za väčšmi kompatibilnú s liberalizmom ako Weberovu.
} 
HEGEL, G. W. F. (1986): Logika ako veda II. Bratislava: Pravda.

HEGEL, G. W. F. (1992): Základy filosofie práva. Praha: Academia.

HONNETH, A. (2014): Freedom's Right. The Social Foundations of Democratic Life. Cambridge: Polity Press.

LUKÁCS, G. (1971): History and Class Consciousness. London: Merlin Press.

MÁRKUS, G. (1997): Political Philosophy as Phenomenology: On the Method of Hegel's Philosophy of Right. Thesis Eleven, 18 (48), 1 - 19. DOI: https://doi.org/10.1177 /0725513697048000002.

MARX, K. (1956a): Kapitál III-2. Praha: Státní nakladatelství politické literatury.

MARX, K. (1956b): Ke kritice Hegelovy filosofie práva. In: Marx, K., Engels, F.: Spisy. Svazek I. Praha: Státní nakladatelství politické literatury, $225-357$.

MODY, A. (2018): EuroTragedy: A Drama in Nine Acts. Oxford: Oxford University Press. DOI: https://doi.org/10.1093/oso/9780199351381.001.0001.

PEPERZAK, A. T. (1987): Philosophy and Politics: A Commentary on the Preface to Hegel's Philosophy of Right. Dordrecht: Martinus Nijhoff.

PEPERZAK, A. T. (2001): Modern Freedom: Hegel's Legal, Moral, and Political Philosophy. Dordrecht: Springer.

PINKARD, T. (2000): Hegel: A Biography. Cambridge: Cambridge University Press.

PIPPIN, R. B. (1997): Idealism as Modernism. Hegelian Variations. Cambridge: Cambridge University Press.

SHAW, C. K. Y. (1992): Hegel's Theory of Modern Bureaucracy. American Political Science Review, $86(2), 381-389$.

STIGLITZ, J. (2016): The Euro. How a Common Currency Threatens the Future of Europe. New York: W. W. Norton \& Company.

VAROUFAKIS, Y. (2017): Adults in the Room. New York: Farrar, Straus and Giroux.

WINFIELD, R. D. (1991): Freedom and Modernity. Albany: Suny.

Táto práca bola podporovaná Agentúrou na podporu výskumu a vývoja na základe Zmluvy č. APVV-15-0682.

Michal Lipták

Filozofický ústav SAV

Klemensova 1

81364 Bratislava 1

Slovenská republika

e-mail: iammichal@gmail.com

ORCID ID: https://orcid.org/0000-0002-4333-6108 